\title{
The Impact of Multinational Companies from Romania on Increasing the Level of Corporate Social Responsibility Awareness
}

\author{
Codruţa Dura' ${ }^{1}$ Imola Drigă'
}

\begin{abstract}
The Romanian business scene has recently borrowed the concept of corporate social responsibility (CSR), and this evolution was due to the presence of multinational companies (MNCs) that implemented new practices and activities in this area. Our paper aims to provide a presentation of social responsibility in Romania, based on public reports of multinational companies, studies and reports of several institutions involved, foreign and Romanian literature or websites and other media sources. After a short review of the literature on the CSR issue, we have described the main coordinates of CSR implementation within the Romanian business environment: authorities and institutions involved in the process, types of initiatives/actions undertaken by MNCs from Romania, and high priority domains of society that benefit from the support of MNCs. A general image of the stage of CSR development in Romania was captured by a strengths, weaknesses, opportunities and threats (SWOT) analysis on the subject. In the final section of our paper, we analysed the case of Petrom OMV Company, the top CSR player in Romania in recent years, in an attempt to prove that we can find remarkable examples of suitable practices and that these experiences must be disseminated within the overall Eastern European business environment.
\end{abstract}

KEY WORDS: $\quad$ Corporate Social Responsibility (CSR), Multinational Companies (MNCs), business environment, transparency, strategic planning

JEL Classification: F23, M14

${ }^{1}$ University of Petrosani, Romania

\section{Introduction}

In recent years, there has been considerable interest in the process of globalization, which is fuelled worldwide by multinational companies (MNCs). These entities spread into every corner of the Globe and reshape economic activities and cultural values within the

\section{-}

Correspondence concerning this article should be addressed to: Imola Drigă, University of Petrosani, Department of Economics, University Street, No.20, 332009, Petrosani, Romania, E-mail: imola.driga@gmail.com countries in which they set operations, regardless of geographical distances and boundaries (Kolk \& Van Tulder, 2010).

Thus, debates encompassing the process of globalization have illuminated many concerns that MNCs may be searching for profit to the detriment of local communities, environmental quality, labour force, and employees (Zaharia \& Grundey, 2011). As a reaction to such judgments, MNCs have increasingly put into place specific policies and programs that strive to highlight their social responsibility as business organizations. 
In Romania, the emergence of corporate social responsibility (CSR) concept is considered the result of two distinct, yet convergent, historical evolutions. The first is the expansion, in the late 90s, of multinational companies based in the Western world; these had the merit of introducing new practices and activities in this sphere. The second followed the moment of Romania's adherence to EU requirements in 2007, when companies were urged to adopt new business behaviour, in accordance with the requirements of the community acquis (Obrad, Petcu, Gherheş, \& Suciu, 2011). Our paper examines to what extent MNCs emerging in the Romanian business environment during the last 20 years can be considered disseminators of CSR best practices within the overall Eastern European region they operate in.

The paper discusses three main research questions: (1) To what extent is the CSR concept beneficial to Romanian society considering the pros and cons of social responsibility from the literature? (2) What are the awareness and implementation levels of the CSR concept in Romania? (3) What kind of role is assigned to MNCs in the process of increasing CSR awareness? (4) Are there examples of best practices within MNCs from Romania regarding the strategic approach of CSR activities?

The paper is organized as follows. The next section is dedicated to the methodological aspects that supported the research strategy used within the paper. Section 3 examines the general framework of the CSR concept by taking stock of the main streams from the literature; given the scale of the literature on the issue, the review is inevitably selective. Section 4 diagnoses the state of implementing the CSR concept in Romania with a special focus on the role performed by MNCs in the process. Section 5 provides a case study of CSR best practices within Petrom OMV, a highly performing MNC based in Romania and Austria. Finally, section 6 concludes.

\section{Methodology}

Our research employs both quantitative and qualitative approaches. In the first instance, we have gathered quantitative secondary data from publicly available sources: national and international reports, European research, academic research papers, on line platforms for CSR activities, websites and CSR studies of na- tional/international organizations, news websites and other on line media sources. Therefore, we performed a data mining process using an up-to-date series of documents and Internet sources, such as: (Anca, Aston, Stanciu \& Rusu, 2011; Braun \& Partners, 2009; Chamber of Commerce and Industry of Romania, 2007; European Commission, 2011; Iamandi, 2010; Săvoiu et al., 2010; Romanian Government, 2011). Given our inquiries regarding the awareness and the state of completion of the CSR concept within MNCs from Romania, data extracted from the sources noted above were the basis of our desk research on the issue. Hence, we were able to build a broad image, at the macroeconomic level, of the stage of CSR adoption by the Romanian business environment.

The validity of the information presented within this paper is supported by the probation of phenomena through multiple sources of information. However, every conclusion bears upon the subjectivity of the authors, as a matter of course.

Second, we have employed a qualitative approach using the case study method to explore "how" certain CSR policies and practices are implemented within Romanian MNCs. We have considered that quality research was the most appropriate approach in this case, because we could thus present certain CSR best practices and show how they could serve as examples for other companies to increase their contributions to society. Our option towards qualitative research rather than quantitative study resulted in a comprehensive presentation of a coherent CSR strategy, which can help other Romanian companies to change their paradigm and make CSR a contributing part of their business.

The case study and the examples presented in this paper call into question relevant quotations from managers and other decision makers involved in CSR programs, outlining the context and the challenges that accompany any situation and reproducing their thoughts and intentions to find the proper solution in every case.

\section{Literature review of the CSR concept}

Terms such as sustainability, sustainable development, corporate social responsibility, corporate conscience, corporate citizenship, corporate social performance, or sustainable/ responsible business are often used in- 
terchangeably in different parts of the world to define the same concept. Nevertheless, the term corporate social responsibility is favoured among European companies in respect of previous failures, whereas in parts of the US, sustainability has anti-corporate connotations.

The term "corporate social responsibility" (CSR) was used before World War II, but in the 1950s, there were limited discussions on CSR. Thus, Abrams (1951) argued that, in a complex world, managers have responsibilities toward their employees, their customers and the general public, while Levitt (1958) warned the business world about the dangers of social responsibility. In 1953, for the first time, Bowen used the concept of "modern CSR" as the obligation for companies to "pursue certain policies, to take certain decisions or to follow those lines of action which are desirable in terms of objectives and values of our society" (Bowen, 1953). Beginning in the late 1960s, the concept grew in importance through academic and business contributions to the literature and through the emerging realities of business practices.

Over time, a large number of definitions have been provided to this concept, from general to more explicit frameworks. A general definition is provided, for example, by Joseph W. McGuire who stated: "the idea of social responsibilities supposes that the corporation has not only economic and legal obligations but also certain responsibilities to society which extend beyond these obligations" (McGuire, 1963, p. 144).

Embracing a stakeholder approach, Harold L. Johnson argues that "a socially responsible firm is one whose managerial staff balances a multiplicity of interests; instead of striving only for larger profits for its stockholders, a responsible enterprise also takes into account employees, suppliers, dealers, local communities and the nation" (Johnson, 1971, p. 50).

Manne \& Wallich (1972) consider that, to exercise CSR, there are three basic activities involved: the setting of objectives, the decision regarding whether to pursue given objectives and the financing of these objectives. In 1980, Thomas M. Jones argues that CRS is "the notion that corporations have an obligation to constituent groups in society other than stockholders and beyond that prescribed by law and union contract".

In the 1990s, the CSR concept transitioned significantly to alternative themes such as the stakeholder theory, the business ethics theory and corporate citi- zenship. One of the major contributions to the interpretation of CSR arrived in 1991, when Donna J. Wood stated that "the basic idea of CSR is that business and society are interconnected rather than distinct entities; therefore, society has certain expectations for appropriate business behaviour and outcomes" (Wood, 1991, p. 695).

An extensive literature review on CSR definitions is provided by Carroll's (1999) Corporate Social Responsibility: Evolution of a Definitional Construct, in which the author covers an impressive history associated with the evolution of the concept and the definition of corporate social responsibility, beginning in the 1950s and continuing into the 1990s.

In more recent studies, corporate social responsibility, related to business ethics, is defined as the "economic, legal, ethical, and discretionary expectations that society has of organizations at a given point in time" (Carroll \& Buchholtz, 2003, p. 36).

With respect to profit oriented firms, there are mainly two different approaches on corporate social responsibility: the classical view (also known as the Agency Theory of CSR) and the socioeconomic view (also known as the social contract approach) (Rath \& Gurtoo, 2012).

The first perspective argues that the goal of CSR is to maximize the profit for the company; it is also called the shareholder approach. This perspective was proposed for the first time by Milton Friedman (1962) and supported by other authors including (Barry, 2000; Coelho, McCLure, \& Spry, 2003; Dvorak, Guth, Landers, \& Zaun, 2000; Henderson, 2005; Jensen, 2001; Rappaport, 1998; Shirouzu, 2000; Sternberg, 1994; Sundaram \& Inkpen, 2004).

The second perspective, based on ethics, claims that businesses owe something back to the society that supports them, and companies are responsible to society as a whole. This approach is favoured by a number of authors worldwide such as (Alchian \& Demsetz, 1972; Carroll, 1999; Freeman, 1984; Jensen \& Meckling, 1976; Lazer, 1996)

Although the prime responsibility of a company is generating profits, companies can at the same time contribute to social objectives, a fact also acknowledged by the European Union. Thus, in 2001, in the Green Paper - Promoting a European framework for Corporate Social Responsibility, the European 
Commission defines corporate social responsibility as "a concept whereby companies integrate social and environmental concerns in their business operations and in their interaction with their stakeholders on a voluntary basis" (Commission of the European Communities, 2001). To fully meet their social responsibility, enterprises should integrate social and ethical human rights and consumer concerns into their business strategy, management instruments and operations. Other actions were taken in 2005-2006 to confirm the idea that European companies have a major contribution to achieving sustainable development strategies at the European level.

Because the employer-employee relationship currently plays an increasingly key role in the vast majority of European companies, in more recent studies there is a growing focus on CSR measures. Thus, Perrini (2005) suggested that the idea of social responsibility is strongly related to the environment and community, while Steurer and Konrad (2009) argued that European companies exert efforts to improve the internal social environment to increase the potential and motivation of their employees.

In general, the methods of influence on companies' social behaviour vary from country to country. However, certain patterns can be identified that have a major impact on the evolution of the concept and the practice of CSR (Brammer, Jackson, \& Matten, 2012).

In 2008, Dahlsrud proposed a five-dimensional model arguing that there are many available definitions of CSR, but each is consistently referring to five dimensions: environmental, social, economic, stakeholders and voluntary. The model, showing that the existing definitions are to a large degree compatible, was developed by the author through a content analysis of existing CSR definitions gathered through an extensive review of the literature, which consisted of journal articles and web pages (37 definitions of CSR were found and analysed) (Dalshrud, 2008).

Currently, corporate responsibility or sustainability is a special feature of the literature that addresses topics such as corporate social performance, business ethics, global corporate citizenship or stakeholder management. References primarily originate from scientific articles, journal articles, books and/or expert essays (Kolk \& Van Tulder, 2010).
In the past decade, a number of significant studies were developed in Romania as well, highlighting specific aspects of CSR practices with specific approaches on the local environment.

There are several arguments for and against corporate social responsibility. Perhaps, the most known "economic" argument against CSR is that associated with Milton Friedman (Friedman, 1970), who has argued that the primary responsibility of business is to make a profit for its owners. The American economist and other authors have stated that "a corporation's purpose is to maximize returns to its shareholders and it does not have responsibilities towards society as a whole". The adversaries of CSR sustain that a free market economy cannot solve social problems; therefore, these issues must be addressed by governments, as they are governments' responsibilities. Of the great personalities against corporate social responsibility, we note Milton Friedman, Peter Drucker, and Noam Chomsky.

Nevertheless, there are many distinct arguments in favour of corporate social responsibility as well, suggesting that "businesses should assume social responsibilities because they are among the few private entities that have the resources to do so". Thus, a research division of The Economist, Economist Intelligence Unit (2008), published global research results, which demonstrate that the financial performance of a company is linked to the performance of CSR. The study shows that investment in CSR is not a barrier to financial performance. Moreover, the study states that, in the opinion of more than 300 CEOs, CSR performance is critical to the overall success of the company. Of the great personalities in favour of corporate social responsibility, we note William Ford (CEO of Ford, grandson of the pioneer in CSR, Henry Ford), Henry McKinell (CEO of Pfizer), and Paul Lichfield (president of Goodyear Tire).

Arguments for and against CSR are summarized in table 1.

\section{Current state of implementing the CSR concept in Romania}

In this section, we shall perform a brief analysis of the status of CSR awareness and implementation in Romania. This diagnosis relies on the investigations made by the authors of the most relevant research papers and articles addressing this issue. 
Table 1. Arguments for and against CSR

\begin{tabular}{|c|c|}
\hline For CSR & Against CSR \\
\hline $\begin{array}{l}\text { The development of modern corporations has created many } \\
\text { social problems. Therefore, the corporate world must assume } \\
\text { responsibility for these problems. }\end{array}$ & $\begin{array}{l}\text { Discussions related to the moral and ethical aspects of } \\
\text { companies are not economically feasible. Companies should } \\
\text { focus on creating profit for shareholders and leave social } \\
\text { issues to more competent bodies in this regard. }\end{array}$ \\
\hline $\begin{array}{l}\text { Assuming social responsibilities benefits companies in } \\
\text { the long run by increasing the chances of success for the } \\
\text { business and reducing the chances of additional regulations } \\
\text { from governments. }\end{array}$ & $\begin{array}{l}\text { Those in the corporate world are not empowered to address } \\
\text { social problems. Business executives and managers are } \\
\text { generally not well trained in dealing with complex societal } \\
\text { problems, and they do not have the knowledge or skills } \\
\text { needed to address these issues. }\end{array}$ \\
\hline \multirow[t]{3}{*}{$\begin{array}{l}\text { Large companies have huge financial and human resources, } \\
\text { and they should use some of these resources to solve social } \\
\text { problems. }\end{array}$} & $\begin{array}{l}\text { Assuming social responsibilities places companies at a } \\
\text { competitive disadvantage relative to those who choose not } \\
\text { to assume such responsibilities. }\end{array}$ \\
\hline & $\begin{array}{l}\text { CSR is developed by the most environmentally damaging } \\
\text { corporations to distract from corporate practices that are } \\
\text { directed against people and the environment. Companies do } \\
\text { "good" to compensate for what they do "wrong". }\end{array}$ \\
\hline & $\begin{array}{l}\text { CSR is another expression of capitalist domination and } \\
\text { corporate power. }\end{array}$ \\
\hline
\end{tabular}

Thus, the study CSR and Competitiveness - European SMEs' Good Practice - National Report Romania, 2007 is one of the reference documents that reveals the causes of the development of CSR in Romania and the indubitable role of multinational companies in this process: The appearance of the CSR concept and of related practices and issues in Romania has two main causes. First of all, the economic development and the entrance of multinational companies into the Romanian market have determined a type of pressure to identify new ways of consolidating the corporate image and reputation. These issues determined more and more sophisticated strategies, while the consumer educated himself and learnt to make appropriate choices. Secondly, the withdrawal from the market of the big donors and the decrease of the financial resources belonging to international organizations determine another type of pressure, on the part of the non-profit organizations that diversify their strategies with regard to attracting finance from sources like the public and business sectors or citizens (Chamber of Commerce and Industry of Romania, 2007 , p. 5). The main promoters of these social responsibility initiatives were multinationals such as Lafarge, Coca Cola, Holcim, Carpatcement, P\&G, Zentiva, Orange, Vodafone, and Petrom OMV; the projects implemented by them strived to solve social problems with high emotional impact on the public: health, education and environment protection.

The third edition of the CORE Conference: CSR and Integration in 2008 notes the participation of professors Alin Stancu and Valerică Olteanu from the Academy of Economic Studies with the paper "Corporate Social Responsibility in Romania from a EU Perspective". The authors perform a very broadly scoped analysis of CSR in Romania, of the parties involved in the implementation and the dissemination of the concept and of the results obtained after this effort. Moreover, the study shows that "multinational companies are the trendsetters in this field, due to their corporate culture. Even though few companies publish CSR reports or include in their annual reports activities regarding CSR. Companies use CSR practices as a tactical instrument; this is why most projects of this kind in Romania are for the short-term". (Dumitru, Ionescu, Calu, \& Oancea, 2011). Therefore, as with any important concept that requires significant qualitative accumulation prior to assimilation, CSR was originally imposed in Romania as a fashion trend more than as a result of the awareness of all stakeholders (Iamandi, 2010, p. 176).

On the $11^{\text {th }}$ of May 2009, Braun \& Partners Network, the leading CSR and marketing consultancy firm in Central Europe, released the results of the CSR 


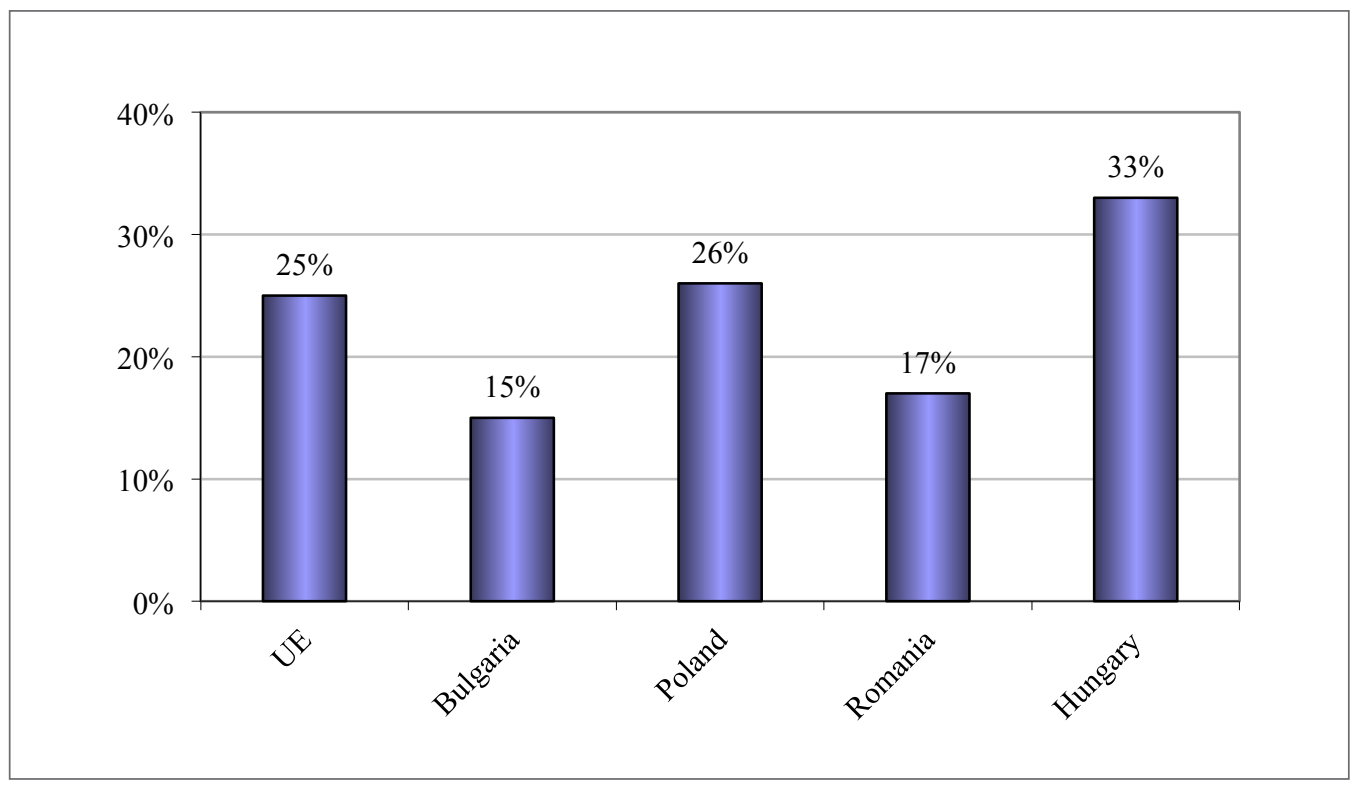

Figure 1. Values of the composite index CSR 24/7 CEE-100 compared with the European average Adapted from: Braun, R. (2009) Cartea Responsabilității Sociale Corporative. Rapoarte scurte ale companiilor româneşti [The Book of Corporate Social Responsibility. Brief Reports of Romanian Companies]. București: Braun \& Partnets S.R.L.

24/7 rating for 4 countries in the Central-Eastern European region: Hungary, Poland, Bulgaria and Romania. The research methodology used by this management consultant is built on the assessment of the CSR performance of companies based on publicly available information accessible to all stakeholders. To perform this analysis in Romania, Braun \& Partners consultants focused on the first 25 companies from the "The Top 100 most valuable companies in Romania” by Ziarul Financiar (Financial Newspaper) (Braun, 2009).

During the preparation of this study (April 2009), a large volume of documentary sources available in public spaces was accessed (web sites, annual reports, and documents). Using this information, an assessment of companies was possible in terms of social involvement, and a rating was determined on the basis of 7 criteria. In order, these criteria were as follows (Braun, 2009):

- transparency and communication - providing information about the company, CSR reports publication;
- corporate governance - transparency of CSR management;

- relationship with interested parties - their identification and systematic bidirectional dialogue;

- responsibility towards the environment - measurements of the materials used and of the emissions;

- economic responsibility - equitable management of suppliers, transparency of the distribution of income;

- society - strategic civil partnerships, donation transparency;

- accountability in human resources - employees' health and safety systems, transparent system of performance evaluation.

The composite index CSR 24/7 CEE-100 calculated in the study measures the performance of regional companies and includes the average results of the first 25 companies from the four countries analysed, weighted with each country's GDP. The composite index of the CSR 24/7 CEE-100 values was 6 points (25\%) for 
Table 2. Top 15 CSR involved companies within Eastern Europe

\begin{tabular}{|c|c|c|c|c|}
\hline Rank & Company & Country & Sector & Total Score \\
\hline 1 & Magyar Telekom Távközlési Nyrt & Hungary & telecommunications & $79 \%$ \\
\hline 2 & OTP Bank Nyrt & Hungary & financial & $73 \%$ \\
\hline $3-4$ & Mol Magyar Olaj-és Gázipari Nyrt & Hungary & energy \& utilities & $71 \%$ \\
\hline $3-4$ & Tiszai Vegyi Kombinat Nyrt & Hungary & industry & $71 \%$ \\
\hline 5 & Grupa Lotos & Poland & energy \& utilities & $60 \%$ \\
\hline $6-7$ & MVM Csoport & Hungary & energy \& utilities & $56 \%$ \\
\hline $6-7$ & Telekomunikacja Polska & Poland & telecommunications & $56 \%$ \\
\hline $8-10$ & E.On Hungária Zrt. & Hungary & energy \& utilities & $54 \%$ \\
\hline $8-10$ & Generali-Providencia Biztosító Zrt. & Hungary & financial & $54 \%$ \\
\hline $8-10$ & K\&H Bank Zrt. & Hungary & financial & $54 \%$ \\
\hline $11-12$ & Grupa Metro w Polsce & Poland & trade & $52 \%$ \\
\hline $11-12$ & MKB Bank Zrt. & Hungary & financial & $52 \%$ \\
\hline 13 & PKN Orlen & Poland & energy \& utilities & $50 \%$ \\
\hline 14 & Petrom & Romania & energy \& utilities & $48 \%$ \\
\hline 15 & Orange Romania & Romania & telecommunications & $44 \%$ \\
\hline
\end{tabular}

Source: Braun, R. (2009) Cartea Responsabilităţii Sociale Corporative. Rapoarte scurte ale companiilor româneşti [The Book of Corporate Social Responsibility. Brief Reports of Romanian Companies]. București: Braun \& Partnets S.R.L.

2009, which led to the conclusion that the average of the companies surveyed was only one quarter of the maximum achievable score. In particular, companies in Romania (which recorded a performance of 17\%) and Bulgaria (15\%) were in the initial stages of CSR performance and communication. At the opposite pole, the "top companies" were in Hungary (with a performance of $33 \%$ ), followed by those from Poland (with a score of 26\%) - Figure 1 (Braun, 2009).

In the regional ranking, CSR 24/7 2009, Magyar Telekom (subsidiary of Deutsche Telekom) was first, with a performance of $79 \%$ for the CSR composite index. OTP Bank Nyrt was second, while places 3 and 4 were occupied by MOL and Tisyai Vegyi Kombinat Nyrt, respectively. At number five was the highest rated company in Poland, Group Lotos, an oil and gas producer with a score of $60 \%$.

The Romanian company with the highest score was the oil company Petrom $\left(14^{\text {th }}\right.$ place in the region, with a score of $48 \%$ ). The best companies in Bulgaria, Asarel Medet (heavy industry) and Kozloduy (an energetic company) occupied the same place (24-28), each with a score of $29 \%$ - table 2.
Despite the low availability of CSR communication, specialists from Braun Partners Romania identify a number of examples of best practices that have already been implemented in the field of Romanian CSR. These organizations cover a large area of domains, such as: banking - BCR (Romanian Commercial Bank); telecommunication - Orange Romania; health - Dona Pharmacy; and interior design accessories and equipment - Romstal. The awareness of CSR activity and ensuring its continuity in the economic crisis conditions of inevitable budget cuts are, in the opinion of the Braun Partners consultants, the germs of the future development of this area.

In the 2010-2012 period, the concern of researchers from the academic and business sectors and the governmental factors from Romania in relation to the CSR issues intensified. The most valuable research reports and technical papers regarding the specifics of CSR in the domestic business environment urge us to focus on the following questions: Q.1. Who are the key actors in the field of CSR in Romania? Q.2. What are the areas of intervention of CSR? Q.3. What are the types of programs/CSR actions Romanian multinationals 


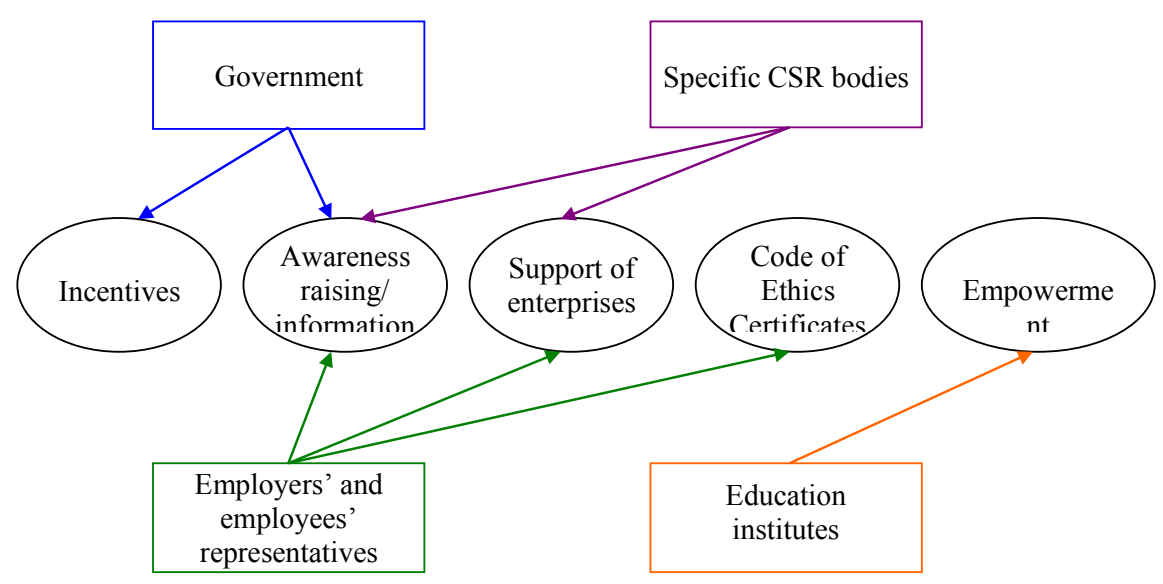

Figure 2. Key actors and their strategies in the CSR field

Adapted from: Anca, C., Aston, J., Stanciu, E., \& Rusu, D. (2011). Responsabilitate Socială Corporativă în România. Analiză situațională şi recenzie a practicilor actuale [Corporate Social Responsibility in Romania. Situational Analysis and Review of Current Practices]. Raport realizat în cadrul Proiectului POSDRU/64/3.3/S/41722 Întărirea capacității companiilor româneşti de dezvoltare a parteneriatelor sociale - RSC [Report within SOPHRD/64/3.3/S/41722 Project - Strengthening the Capacity of Romanian Companies to Develop Social Partnerships - CSR]. Retrieved from http://undp.ro/libraries/projects/CSR/deliverables/Analiza\%20Situatiei\%20RSC\%20in\%20Romania\%20RO(1).pdf

become involved in? Q.4. What are the main strengths and weaknesses of the Romanian CSR?

\section{Q.1. Who are the key actors in the field of CSR in}

Romania? CSR-related activities involve a number of common responsibilities for a large number of actors, including public authorities, the private sector, society as a whole and educational institutes (Anca et al., 2011).

Figure 2 shows a summary of the key actors and their specific intervention methods, as described below.

The role of public authorities is to provide a legal environment conducive to the operation of the CSR concept (Bondy, Moon, \& Matten, 2012). The documentary sources analysed that formed the basis of our research have revealed that, after Romania's integration into the European Union, significant improvements were made to the normative acts concerning the protection of the environment, the health and safety of employees, the social inclusion of people with disabil- ities, voluntary work and civil protection, and transparency and anti-corruption. (Săvoiu et al., 2010).

Public authorities have taken a series of efforts towards increasing the awareness of CSR in Romania, particularly after the elaboration and the dissemination of a National Strategy to Promote Social Responsibility in Romania 2011-2016 (Romanian Government, 2011). There developed, in this context, a number of important initiatives and events in the Romanian business environment: seminars, conferences, studies, design of web-sites devoted to one or more specific CSR issues: the prevention and reduction of pollution of the environment, equal opportunities for men and women and the elimination of discrimination at work, the promotion of road safety, emerging organic market development, encouraging research, art, culture or sport. With regards to the actual involvement in CSRtype initiatives, the number of projects involving insti- 
Table 3. SWOT analysis of CSR in Romania

\section{Strengths}

- Aperture and the general interest of society for CSR and the relative novelty of the concept in the public space;

- The existence of a transfer of know-how from the multinationals with a strengthened corporate culture towards the Romanian business environment in the sphere of implementation of CSR initiatives;

- Continued growth in the number of CSR initiatives and best practices in this field at the national level;

- The existence of modern communication platforms, networks, forums, blogs and websites, in the field of social responsibility as a source of information in this field and an instrument for the dissemination of the concepts and suitable practice of CSR in society;

- The tendency of SMEs to switch from philanthropy work and volunteering to more advanced forms of intervention in the field of CSR, such as socially responsible corporate practices;

- The orientation of CSR programs toward intervention areas "sensitive" from the perspective of Romanian society: community problem solving, environmental protection, education, etc.

- Increased interest of consumers for the products/ services of socially responsible companies

Weaknesses

Insufficient knowledge of the concept of CSR at the company level;

- Lack of studies, research and extensive sociological evaluations on the degree of knowledge and implementation of CSR in Romania;

- Poor knowledge and implications of organizations and SMEs in CSR initiatives;

- Poor coordination of CSR key actors as regards CSR programs, against the background of insufficient involvement of some of them (governmental authorities, employee representatives, research/education institutions);

- Insufficient financial resources for CSR programs, which have undergone additional reductions during the crisis;

- Certain Romanian business organizations still perceive CSR as a tool for PR (public relations), and they implement it by the mere "imitation" of the specific practices of multinational companies;

- The absence of university specializations in the field of CSR, as well as training and development courses of specific competencies;

- Lack of consistency with regard to the integration of the CSR strategy in the global business strategy of the company.

\section{Opportunities}

Threats

- Benefits for companies, communities, society, and business environment of a strategic approach of companies that integrate CSR;

- The importance accorded to the concept of CSR at the European and international levels;

- Opportunities for development and involvement in the European/international market for SMEs;

- The opportunity to learn, take over and adapt the best practices and lessons learned from the experience of more developed states due to the presence of MNCs in Romania;

- Increase of the importance of the reputation of companies, environmental policies in the consumers' . choices;

- Funding opportunities for CSR initiatives offered by the EU;

- Positive attitudes of citizens regarding the involvement of companies in the community/society;

- An environment protected against the negative effects of human activities.

Source: Adapted from Strategia Națională De Promovare a Responsabilitatii Sociale 2011-2016 [National Strategy to Promote Social Responsibility in 2011-2016] by Romanian Government (2011). Retrieved from http://www.sgg The absence of coherent and consistent legislative framework;

- Deficiencies in law enforcement;

Delays regarding acceptable standards in CSR-related domains (e.g., environment) in comparison with other EU Member States;

The risk of exclusion/blocking the access of Romanian companies in certain markets;

Insufficient support and implication of public authorities in promoting and implementing CSR;

The lack of budgetary funds for promoting the implementation of CSR. 
tutions and public authorities continues to be reduced, and the role they assume is most often as a secondary partner and not the main promoter (Anca et al., 2011).

Representatives of employees and employers also contribute to fostering the implementation of responsible business practices. The Chamber of Commerce and industry is the actor in this category with the most visible presence on the scene of CSR initiatives; it provides the logistics required to implement related projects at the national and local levels through its regional offices. In table 3 there is a summary of these projects; the majority of these are conducted by accessing EU funds. Unfortunately, the professional organizations have not yet demonstrated that they understand the beneficial effects that they may have within the society, contributing to the creation of a business environment. However, there are two positive examples of professional organizations involved in CSR-type projects: the General Union of Industrialists of Romania, which has implemented a project aimed at training 800 people in the area of lobbying and advocacy to transform social dialogue into an effective working practice, and the Federation of Cement Unions from Romania, which is an active campaigner for the transfer of knowledge and suitable CSR practices within the cement industry (Anca et al., 2011).

With regard to specific CSR bodies and organizations, these are mainly represented by modern communication platforms, networks, forums, blogs and websites, dedicated to issues of social responsibility and sustainable development. Located at the interface between civil society and public/private organizations, on-line communication platforms are an extremely rich source of information in the field, such that their operation is vital from the perspective of disseminating concepts and CSR practices within society, of promoting and stimulating theoretical debates and case studies, and of providing practical tools and reference models at national and international level. The most relevant communication platforms in the field of CSR are the following: Responsabilitate Sociala.ro, CSR România, Responsabilitate -Sociala.org, CSRMedia, Acţionăm Responsabil.ro, and ŞtiriONG (www. responsabilitatesociala.ro, www.csr-romania.ro, www. csrmedia.ro, www.actionamresponsabil.ro, and www. stiriong.ro). One of the latest surveys based on questionnaires that were answered by 15 representatives of multinational companies from Romania revealed that the main source of information about the CSR theme is represented by on-line networks, blogs and newsletters; only then are these followed by "conventional" sources such as magazines, newspapers, or books (Obrad et al., 2011).

The role of education and research institutions is, in theory, to contribute to a better knowledge of the CSR field at national and international levels and, pragmatically, to ensure the training and the development of skills for CSR. Regarding organizing conferences, seminars and workshops in this field, educational institutions have been established into cores of debate and dissemination of the most important results and best practices in the field, but they have not used properly the opportunity to contribute to the professionalization of CSR through the creation of a university curriculum adapted to the latest developments in the business environment encompassing dedicated programs. Thus, it appears that CSR is not the subject of bachelor or master degree programs in Romanian universities. Some levels of this domain (business ethics, environmental protection, community relations) may form packs of subjects within the curricula of academic programs such as Social Assistance, Management, Marketing, Communication, but these only tangentially address the impact of businesses upon the environment or the contributions of companies to society through the promotion of responsible business behaviour (Anca et al., 2011).

Q.2. What are the areas of intervention of CSR? The website www.responsabilitatesociala.com extensively presents suitable practice examples of multinational companies that conduct businesses in Romania and are socially responsible. According to the website, the most important categories of CSR projects implemented by companies in Romania during the 2007-2012 period were in the following areas of social involvement: (1) social (community): Petrom OMV, Germanos Telecom Romania, GlaxoSmithKline (GSK) Romania, Holcim Romania, JT International Romania, Orange Romania, LaborMedPharma, The Rompetrol Group, Vodafone Romania, Zentiva, and A\&D Pharma; (2) education: Orange Romania, OTP Bank, Banca Comercială Română, RBS Romania, Petrom OMV, Coca Cola HBC, SIVECO Romania SA, Carpatcement Holding, and Holcim Romania; (3) 


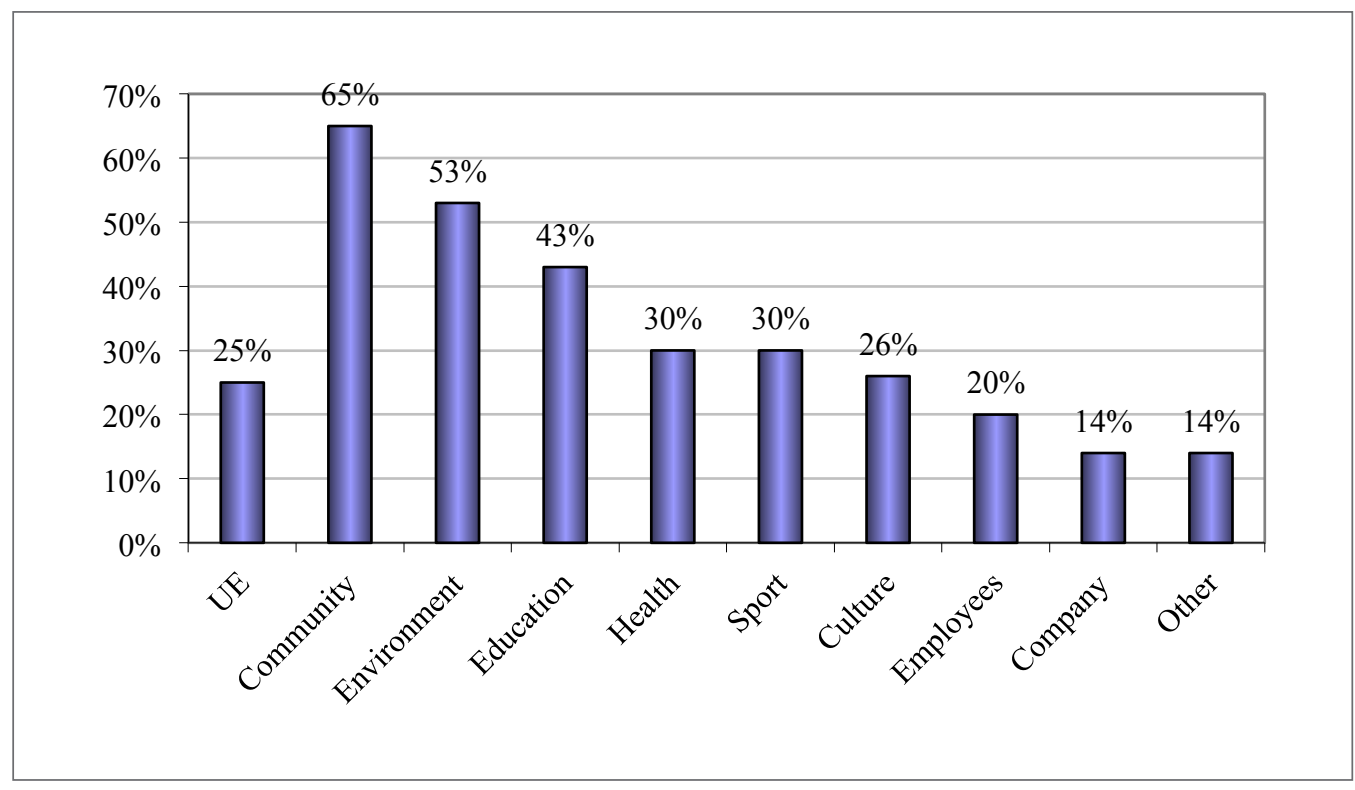

Figure 3. Areas of social involvement of Romanian companies

Adapted from: Băleanu, T.E.; Chelcea, L.; Stancu, A. (2011) Responsabilitatea socială corporatistă a primelor 100 de companii din România. O analiză a Website-urilor corporatiste (The Social Responsibility of the Top 100 Romanian Companies. An Analysis of Corporate Websites). Amfiteatru Economic, 13(29), 235-248.

culture: Apa Nova, Coca Cola HBC, Banca Comercială Română, JT International Romania, MOL Romania, SIVECO Romania SA, Smithfield Prod, UPC Romania, Vodafone Romania, and Zentiva; (4) environment: Petrom OMV, Orange Romania, MOL Romania, Coca Cola HBC, Cosmote, Dacia Groupe Renault, JT International Romania, LaborMedPharma, and Terapia Ranbaxy (www.responsabilitatesociala.ro).

A clearer and more trustworthy presentation of MNCs' areas of intervention in Romania is made by Băleanu, Chelcea and Stancu (2011). The authors built a database based on the investigation of 100 websites of companies included in the ranking made by the publication Ziarul Financiar (Financial Newspaper), according to indicators such as market capitalization (if the company is listed on the stock exchange), financial performance in recent years, value of transactions conducted on the market, and level of debt and market shares. With regard to the areas of intervention of the
CSR programs implemented by these companies, there were eight major areas of action identified (Figure 3).

Approximately $65 \%$ of the companies investigated note the community as the main target of CSR arrangements. The interventions in this area are focused on the settlement of problems related to the social protection of persons in difficulty, which include the following: the construction of homeless shelters, empowering and educating the population with regard to intervention in emergency situations, supporting people with disabilities, assisting victims of natural disasters, offering gifts to people in difficulty during the holidays, and educating the general public to prevent serious diseases (cancer and AIDS.).

As regards the environment, which is noted by $53 \%$ of companies as a priority sphere of action, the projects developed in this field focused on generating innovative solutions to complex problems, such as greening campaigns or planting green spaces, recycling, reduc- 
ing urban pollution or designing and bringing to market new versions of "eco" products/services, friendly from the perspective of the impact they have upon the environment (they are particularly welcomed as they are developed by companies from the oil industry, the automotive industry and the tobacco industry).

There are several situations in which environmental protection programs are correlated with the education sector, thus contributing to the youth's awareness of the need to include care for the environment among their fundamental values (that is, the initiatives " $F u$ ture Parks", "Think Ahead" and "Andrei's School" promoted by Petrom-OMV multinational company). The third area of CSR intervention, which is represented by $43 \%$ of the companies that formed the subject of this study, is education. The programs implemented in this sphere have materialized in the form of scholarships granted to pupils and students, in the organization and financial support of courses for acquiring specific practical abilities in various professions, in sponsoring extracurricular actions (workshops, competitions, and festivals), and in supporting student communities and associations.

Q3. What are the types of programs/CSR actions the multinational companies of Romania get involved in? The literature provides practitioners with a highly relevant typology of CSR programs that can be operated by large corporations. Developed by Philip Kotler and Nancy Lee in the Corporate Social Responsibility: Doing the Most Good for your Company and Your Cause, this classification indicates six distinct forms of social responsibility (Bibu, Năstase \& Gligor, 2010; Kotler \& Lee, 2005): (1) corporate promoting of social causes, in which the company provides financial resources and other support, fundraising and volunteering to focus upon social issues; (2) marketing associated with social causes, in which the company donates a certain percentage of the income from a given period in favour of supporting social causes; (3) corporate social marketing, through which the company supports the efforts to change the social behaviour oriented towards health improvement and/or public safety, protecting the environment or the welfare of the community; (4) corporate philanthropy, through which a company directly supports a social cause or a charity action in the form of material or financial donations, granting scholarships, facilities or services of various categories; (5) community volunteering, in which a company stimulates its own employees and business partners to become involved in social projects to support the community, an NGO or a cause; and (6) socially responsible corporate practices, which involve a strategic approach to CSR issues through the commitment of the company to voluntarily improve its methods of doing business in such a manner as to lead to sustainable development of the community and to contributions that increase the quality of life.

Relevant case studies presented on the online platform ResponsabilitateSociala.ro demonstrate that there are sufficient examples within the MNCs of Romania for each type of CSR approach noted above. In fact, one may find that the majority of Romanian companies favour more types of CSR actions performed in parallel; unfortunately, there remains a small number of companies that place all these initiatives under the shadow of a holistic and consistent business philosophy (www.responsabilitatesociala.ro).

Recent statistical studies that have examined, among other things, the types of programs MNCs operate with in Romania have led to the conclusion that nearly half focus (entirely or partially) on corporate philanthropy by donating money or goods for financing projects, events or institutions, with the transfer of the administrative responsibility to the beneficiary parties (Băleanu et al., 2011). Considered an instrument of CSR, philanthropy generally fits into business strategies, targeted to the immediate marketing objectives such as protecting and improving the company's image. In addition, this form of social involvement is the most convenient for the company from the perspective of the trained resources and the organizational efforts to be performed; therefore, this is considered a symptom of a poorly structured approach to the CSR strategy.

However, in the Romanian business environment, one may find a significant percentage of companies (approximately 36\%) that develop their "own projects" of social responsibility; they strictly deploy the internal resources of the company to achieve social goals. Since the initiation and coordination of CSR actions often imply an important volume of financial, human and material resources, this form of 
involvement is associated with a strategic approach, such as socially responsible corporate practices (Băleanu et al., 2011).

Q.4. What are the main strong points and weaknesses of Romanian CSR? During the last period in Romania, there were several studies published that meant to highlight the strengths and weaknesses of Romanian CSR. Publishing was as an action that was extremely necessary from the global image perspective of the current status; it coordinates the evolution of this concept in the future. Notable among the most relevant sources of information are the National Strategy to Promote Social Responsibility in Romania 2011-2016, as well as a number of reference works published in the prestigious scientific journal Amfiteatru Economic, which is published by the Academy of Economic Studies of Bucharest (Băleanu et al., 2011; Dumitru et al., 2011; Obrad et al., 2011; Zaharia \& Grundey, 2011). Based on these publications, as well as on the conclusions derived from those presented above, we have developed the strengths, weaknesses, opportunities and threats (SWOT) analysis table of CSR in Romania, which is presented in table 3.

The inventory of the weaknesses covers an area of extremely heterogeneous concerns involving, among other things, insufficient knowledge of the concept of CSR at the company level and a lack of studies, research and extensive sociological evaluations of the degree of knowledge and implementation of the CSR in Romania. Although multinational corporations entered the Romanian market in the 1990s, providing a series of practices and strategies for social responsibility, the CSR concept was a mimetic exercise (Giumali, 2008); it found effective applicability in the Romanian business environment after the country's accession to the European Union in 2007. With the need to comply with European legislation, Romanian companies have begun to develop a behaviour that is actually connected to the community acquis. This behaviour, however, is by far the attribute of large multinational companies. Consequently, insufficient knowledge and involvement of organizations and of SMEs in CSR initiatives is another weakness revealed by the literature in Romania (Anca et al., 2011).

The same category includes the superficial involvement of business organizations in CSR activities (without treating the causes of the social problems) and the extent of socially responsible investments and acquisitions. In conjunction with the results of other literary studies, we can consider the following as the main weaknesses of Romanian CSR: the financial resources remain very limited, the transparency of CSR programs is insufficient and the CSR policy does not comply with the global strategy of the company. In addition, CSR is viewed as a tool for PR (public relations), particularly because it is done voluntarily and it is not registered among the legal requirements for business conduct. Moreover, there are voices that state that CSR is used in Romania as a PR tool, which is materialized in specific investments, donations or sponsorships, to the detriment of long-term programs (Obrad et al., 2011).

Conversely, among the strong points, we can note the involvement of a growing number of companies in CSR-type activities, the diversity and the originality of implemented projects, as well as the constant increase of the interest of society and the public opinion of social responsibility programs implemented by local or multinational companies (Obrad et al., 2011). Moreover, the studies conducted in recent years have highlighted the tendency of large corporations to evolve from low cost methods of action at the organizational level (sponsorships, philanthropy or volunteering) to socially responsible corporate practices involving a strategic approach to CSR issues in the context of the implementation of a business philosophy that is oriented towards the welfare of the community and the protection of the environment. The orientation of CSR programs towards the main areas, such as social needs, environmental protection and education, must also be highlighted as a positive aspect. This orientation is prominent, given the conditions that lead Romania to be one of the weakest performers regarding the environment in the EU. However, the modest economic performance recorded at the national level in recent years has resulted in a low quality of life level and in a series of obstacles to educational access for certain social categories.

Beginning with the strengths and weaknesses, the following question naturally arose: "What can we expect in 2013 in Romania regarding social responsibility?" The results of interviews conducted with prominent specialists in the field and posted on the www.responsabilitatesociala.ro communication plat- 
form lead to the following answers: the emergence of new players in the market (medium-sized companies); great pressure upon the public sector to increase transparency; the development of strategic partnerships between large companies and NGOs, which promote, through their financial support, various programs and social causes and a strong commitment for corporate responsibility through its integration into the vision/ core values of the organization (www.responsabilitatesociala.ro).

\section{Petrom OMV - The top CSR player in Romania. A case study}

Petrom is the largest Romanian oil and gas company, with activities in the following areas: Exploitation, Production, Refining, Marketing and Petrochemicals. Since December 2005, Petrom has been a member of the OMV Group. Together, the two organizations form the largest integrated oil and gas group within Central and South-East Europe. (www.responsabilitatesociala.ro).

The company has facilities of exploitation and production in 20 countries around the world. In 2011, the turnover of the group was 5.336 million Euros, while the EBIT (Earnings before interest and taxes) was 1.165 million Euros. According to the annual report for 2011, the number of employees of OMV Petrom decreased by $7 \%$ in 2011 to 22,912 people, which is less than half that in 2005, when the company was taken over by the Austrian OMV Group (Dura \& Isac, 2012). Table 4 presents the financial and operational results registered by Petrom in the 2009-2011 period in detail. Despite a relatively turbulent macroeconomic environment, the company achieved very strong financial results in 2011 compared with the previous year, registering remarkable increases in certain indicators, such as the net profit attributable to the shareholders of the parent company, the cash flow from exploitation and the return on average capital employed.

In 2012, Petrom remained the leader of the most valuable companies with domestic ownership ranked by the Financial Newspaper and the Capital Partners Investment House. Valued at 4.98 billion Euros, the company owns nearly twice that attributed to the first five companies with Romanian private capital, which are the following: RCS\&RDS, Interagro, Banca Transilvania, Dedeman or Mediplus Exim.
According to Botezatu (2012) the largest company in Romania, Petrom, is also the largest investor in social responsibility projects, with a budget valued at 4.2 million Euros in 2011. This budget represents more than one quarter $(25.9 \%)$ of the total amount invested by Romanian companies in CSR in 2011, 16.2 million Euros. Petrom's commitment to conduct its businesses in the context of taking responsibility for society and the environment has been a tradition for 5 years. Thus, the statistical data of the company shows that, in the 2007 2011 period, Petrom invested no less than 27,500,000 Euros for the design and implementation of CSR programs in five main areas of involvement: environment, education, health, community development and employee relationships (Petrom, 2011b).

The manner in which the CSR policy is integrated into the global strategy of the group is analysed based on the information collected from the companies' websites, www.petrom.com and www.omv.com, as well as from the communication platforms within the CSR field: www.responsabilitatesociala.ro/companii/ petrom.html and www.csrmedia.ro. To understand the role that the CSR policy plays within the strategic planning of the corporation, we used 3 indicators considered relevant in the specialized literature: (1) the extent to which CSR is noted, particularly in the planning and communications of the company; (2) the existence of CSR reporting; and (3) the size of the section within the website dedicated to CSR issues (Băleanu et al., 2011).

Policy guidelines in the CSR field are explained by Mariana Gheorghe, CEO of Petrom, on the website, www.responsabilitatesociala.ro: "The corporate social responsibility is an integral part of the strategy of Petrom. In this way, we want to make sure that we fulfil the responsibility towards the society, through programs that generate not only long-term results but also attitude. First of all, we want every employee of the company to have socially responsible behaviour and to improve business practices by strengthening the Corporate Governance policy. At the same time, being the largest company in Romania, Petrom is committed to contributing actively to the development of the Romanian society. Therefore, we bring our long-term contribution to creating a better world, both for present generations and for those to come. We thus show 'Respect for the Future!" And this is why we have chosen 
Table 4. Petrom's Operational and Financial Results during 2009-2011

\begin{tabular}{|c|c|c|c|}
\hline Operational Results & 2009 & 2010 & 2011 \\
\hline Total production (barrels of oil equivalent) & 68.29 & 67.08 & 67.77 \\
\hline The degree of refinement capacity utilization (\%) & 65 & 49 & 79 \\
\hline Total sales of refined products (mil. tons) & 6.18 & 5.47 & 5.23 \\
\hline The number of distribution stations & 814 & 801 & 793 \\
\hline The number of employees at the end of the period & 28984 & 24662 & 22912 \\
\hline Financial Results & 2009 & 2010 & 2011 \\
\hline Sales (mil. lei) & 16090 & 18616 & 22614 \\
\hline EBIT (mil. lei) & 1620 & 2986 & 4936 \\
\hline Net income attributable to parent company shareholders (mil. lei) & 860 & 2.201 & 3.757 \\
\hline EBIT CCA excluding special elements (mil. lei) & 1870 & 3.325 & 5.475 \\
\hline Net income attributable to parent company Shareholders excluding special elements (mil. lei) & 1056 & 2457 & 4206 \\
\hline Operating cash flow (mil. lei) & 2726 & 4630 & 6442 \\
\hline Investments (mil. lei) & 4219 & 4863 & 4803 \\
\hline Earnings per share (lei) & 0.0152 & 0.0389 & 0.0663 \\
\hline ROACE. Return on Average Capital Employed (\%) & 5.2 & 10.7 & 17.3 \\
\hline
\end{tabular}

Source: Petrom. (2011b). Annual Report. Retrieved from Retrieved from http://www.omvpetrom.com/SecurityServlet/secure? cid=1255738836600\&lang=ro\&swa_site=\&swa_nav=\&swa_pid=\&swa_lang=.

this name for our CSR programs." To identify the CSR policy in the overall planning of the company, we have checked the links "Mission and vision", "Our values" and "Petrom Strategy" on the company's website. We found that, although the mission does not refer explicitly to CSR issues, it incorporates references to the sustainability of the work conducted, as well as to the role it has within the community and in the relation with the most important categories of stakeholders: "We discover, produce and process oil and gas and distribute fuel and other petroleum products to ensure energy and mobility in Romania and in neighbouring regions. The profitable and sustainable growth of our company is good for shareholders, customers, employees and for the economy in general and therefore, it is the goal of all our activities" (Petrom, 2012).

An important section of the website is dedicated to the Global strategy of Petrom Group. According to the CEO of Petrom, Mariana Gheorghe: “...Strategic directions of Petrom for 2021 reconfirm the ones existing in the strategy for 2015, thus ensuring continuity in the development of the company, and they correspond to the strategies of the OMV Group for 2021. Petrom intends to remain an integrated company of oil and gas in the region, with the sustainable performance required to support the potential growth in the upstream segment of the region of the Black Sea. We believe that Romania has a significant potential for energy supply, which can reduce the dependence on imports". Petrom is well-positioned to support the energy sector, thus contributing to Romania's economic growth. After highlighting the most important objectives grouped by activity segments, Exploitation and Production, Gas and Energy, Refining and Marketing, the strategy reviews the main pillars of the implementation of these objectives. Thus, Petrom focuses on two key factors for the successful implementation of its strategy: people and sustainability. With regard to the employees, the emphasis lies on developing an organizational culture based on performance and on a background of talents. "Equally important, we seek to develop a culture of sustainability, based on the efficient use of natural resources, and to share the value with the interested parties for a long-term common benefit (www.petrom.com). Therefore, the role of stakeholders and of the company's employees is a cardinal one, which sets conditions for the process of achieving strategic objectives and ensures the sustainability of businesses in the future" (Petrom, 2012). Hence, the 
Table 2. Top 15 CSR involved companies within Eastern Europe

\section{The Dimension Examples of phrases from the company's official documents}

The Environ mental

Dimension

The Social

Dimension

The Economic

Dimension

Stakeholders

Dimension

Volunteering

Dimension
"To minimize the impact of our operations on the ecosystem, we are committed to sustainable resource management. These efforts include efficient use of water, proper waste treatment and disposal, sensitivity to areas of high biodiversity and prevention of harmful emissions" Sustainability Report, 2011

"In 2011, Petrom has accumulated 5 years of projects dedicated to Romania - projects which are meant not only to reduce the impact the activity of the company has upon the Romanian community but also to help solve the problems of society as a whole. We started gradually - the first initiatives were focused on environmental protection and on the promotion of a responsible attitude towards natural resources. Then, we continued with important investments in the Romanian education system - from the reconstruction of schools to projects of non-formal education, which aim to open the students' horizons, as well as the teachers' horizons. There followed the support of the national health system through partnerships with the Ministry of Health and SMURD, trying to give a chance for life to as many people as possible by extending the telemedicine emergency system and rewarding doctors in Romania" Mariana Gheorghe, CEO Petrom, CSR Report Petrom 2011

"Looking back, 2011 was a year of exceptional operational performance and solid financial results for PETROM, although there were a number of external challenges. These achievements are the result of sustained, significant investments, of an efficient management of costs and operations as well as of favourable crude oil prices. Due to the commitment of our employees, we have continued to achieve results by capitalizing on the integrated business model of Petrom, the key element for the creation of value and one of our strategic directions. In this respect, we have successfully implemented programs to increase efficiency, and we continued to optimize our operations". Mariana Gheorghe, CEO Petrom, Annual Report Petrom 2011.

"Stakeholder Engagement is an integral part of the Resourcefulness concept. Getting to know the interests and views of our stakeholder groups helps us identify future challenges and constantly improve our performance. Our stakeholders include investors, customers, employees, communities, suppliers, authorities and others. By engaging in dialog with all interested parties, our goal is to earn trust and build lasting relationships". Sustainability Report, 2011.

"Through all the social responsibility programs, Petrom intends to promote volunteerism, both for workers and among the partners of the company. In 2011, in addition to the direct involvement of employees in specific actions organized by the company (such as planting, social campaigns, etc.), Petrom has created an internal platform through which employees can get involved in the development of the communities they live in by participating in voluntary initiatives of nongovernmental organizations, which are active in the region. Moreover, Petrom has continued to acknowledge and to reward the voluntary involvement of the staff in community projects through the "Volunteer of the Year" Award, granted to the most dedicated volunteer from Petrom at the end of the year during the Annual Meeting of the company's management. In 2011, in addition to 'The Volunteer of the Year ', team work was also rewarded through a special award granted to the most reliable team of volunteers within the company". CSR Report Petrom 2011.

Source: Adapted from How Corporate Social Responsibility is Defined: An Analysis of 37 Definitions Corporate Social Responsibility and Environmental Management, Corporate Social Responsibility by Dahlsrud, A. (2008) in Environmental Management, 15, 1-13. 
employee's role is an essential one, which conditions the very process of achieving strategic objectives and ensures the sustainability of the business in the future.

With regard to CSR reporting, on the company's website, there are both the CSR Report for 2011 and the Sustainability Report drafted in English and published by OMV Aktiengesellschaft in September 2012 (Petrom, 2011a; OMV, 2011). An important section of the www.petrom.com website is dedicated to the presentation of the Report of CSR activities for 2011 and to projects implemented by the company in the fields of education, health, environment, community development and employee involvement. Moreover, the information presented is supported by suggestive graphic representations, relevant testimonies and photographs from the perspective of the implemented projects' societal impact. On the same webpage, one can access the CSR Reports Archive of Petrom from 2007-2008, 2009 and 2010.

Another section that is as rich in information is dedicated to sustainability issues. The company's efforts in the sustainability direction are related to health, safety, security and environment (HSSE), community relations and social programs. In addition to its own presentation of the Sustainability Report, a series of information, photos, and statistical data regarding dialogue with the stakeholders, the sustainability strategy, sustainability management, community relations and social programs can be found posted on the site. (www.petrom.com).

However, a Sustainability Report extended to the entire OMV Petrom Group can be found on the Austrian Group's website, www.omv.com. One study's conclusions indicated that only $10 \%$ of the companies engaged in CSR in Romania had posted at least one report of CSR activity on the website over the last three years. Therefore, we appreciate that the management of Petrom provides access to an important volume of data, referring not only to 2011 but also to the economic and social impact of CSR projects implemented in Romania in the past five years (2007-2011). We shall later review this data; however, in this section of the paper, it is important to note that this high level of transparency is largely because Petrom is part of the Austrian OMV Group, and the social responsibility report is done at the group level, integrating its experience. There are voices that note that, despite the volume of information the company makes available, they do not note the contributions of the company in terms of reducing carbon emissions or with regard to the impact of the economic activities conducted by the company upon the communities living in the heavily polluted areas where Petrom operates (Ploieşti-Brazi, Romania) (Zaharia \& Grundey).

Noting the existence of a coherence between the CSR policy and the strategic planning of the corporation, one can identify the key elements that ensure the integration of Petrom's approach with the precepts of the model "the five dimensions of CSR", proposed by Dalshrud (table 5).

As regards the fields of involvement in which Petrom conducts CSR initiatives, they are nearly identical to the main CSR areas identified at the national level: community development, education, environment, health, and employee involvement. We perform a brief foray into the leading programs implemented by Petrom in the 2007-2011 period, without issuing an exhaustive claim; this is done to form an overview of their innovative character and the impact on the Romanian society (Dura \& Isac, 2012; Petrom, 2011a):

(1) Ţara lui Andrei.ro (Andrew's country.ro) - stimulates the direct involvement of citizens in solving the problems of the community they live in. Planting within "Ţara lui Andrei" is an activity related to the previously noted educational project that strives to provide more "green" on Romania's map by planting trees in areas affected by landslides or deforestation or in regions characterized by high levels of pollution;

(2) Şcoala lui Andrei (Andrew's school) - coordinated by their teachers, students suggest solutions to solve the problems of the community;

(3) The Circle of Community Resources - a form of community organization composed of representatives of local authorities, community members and representatives of Petrom that seeks to meet the needs of the community through effective involvement in solving their issues;

(4) Eco Businesses in the Danube Delta - stimulates entrepreneurs who want to develop a business in ecotourism, thus capitalizing on the natural, touristic and cultural potential of this protected natural area;

(5) Aspire Academy - consists of organizing a summer school for a week that has invited lecturers, 
Harvard Business School professors, graduates of top universities from the United States and Europe, and successful managers from the Romanian business environment as participants. Participating students have the opportunity to participate in the most efficient educational system, with free debates, stimulating pro-activity and analysis of authentic case studies;

(6) Access to Life - the objective was to support the emergency medical system by expanding the telemedicine network (with a coordination centre within Floreasca Emergency Hospital), providing additional professional training and rewarding physicians of excellence;

(7) Volunteering within Petrom - employees are encouraged to participate in voluntary actions supported by Petrom, including the following: planting trees, supporting socially disadvantaged children, supporting the emergency medicine network, and involving themselves in the local CSR projects implemented by NGOs.

It is worth noting that most CSR programs implemented by Petrom have continuity from one year to another. In the education field, the projects, Andrei's School and Andrei's Country, have developed in an interdependent manner. The projects have been extended each year, and they have greatly impacted both the education system and the protection of the environment. In the 2007-2011 period, more than 21,000 students and 1,500 teachers participated in the civic involvement lesson from the "Andrei's School" project. Eight hundred solutions were proposed and implemented within the communities that applied for this project, and the awards for the re-equipment of the winning schools totalled 114,000 Euros; with this help, 14 other community projects were also implemented (Petrom, 2011a).

Moreover, 570,000 trees were planted on 100 acres of land under the projects "Andrei's Country", "Romania Grows Roots" and "I Drive, therefore I Plant?" In addition to stimulating civic initiative, the project "Şcoala lui Andrei.ro" motivates voluntary involvement as well. Following the outcome noted above, "Şcoala lui Andrei.ro" was considered the most powerful platform for volunteering after Greenpeace by Romanian youngsters, according to a study ordered by
MaiMultVerde and conducted by GFK Romania (www. responsabilitatesociala.ro).

By creating the "Access to Life" platform, Petrom has made an investment of 650,000 Euros in the Romanian health system. Of the amount allocated to this investment, Petrom has directed 450,000 Euros towards the development of the emergency telemedicine network within Târgu Mureş Clinic. Sixteen other hospitals were included in this network and connected to the coordination centre within Floreasca Emergency Clinical Hospital in Bucharest. The current network comprises 56 hospitals from 19 counties in Romania, from which 9.5 million people may benefit. According to the same initiative, Petrom has donated three fully equipped ambulances to the National Medical Emergency Service (SMURD); these are worth over 170,000 Euros (Dura \& Isac, 2012).

The CSR report published by Petrom in 2011 is extremely generous in the presentation of statistical data related to the impact of the company's projects on the quality of life of the people within the communities involved. However, beyond these figures, one positive aspect of the analysis is related to the mutation of the paradigm of Petrom managers working in the CSR field; in addition, in a long-term vision, it evolves towards a strategic approach of socially responsible corporate practices. In this respect, the declaration of Mrs. Mona Nicolici, Head of Community Relations and Social Affairs for Petrom, regarding the company's CSR strategy for 2012, which is posted on the CSR media website, is very relevant: "The new CSR strategy of the OMV Group - called "Resourcefulness" lays emphasis on sustainability. The main idea is to use the resources that the company handles responsibly, whether they are natural, human or financial resources. Starting from this new strategy, we have chosen as the main guideline the development of the communities in which we operate. Through the actions that derive from this strategy, we wish to involve the business and the people who handle businesses in activities that support communities. Moreover, through the projects we carry out, we want to teach people and communities about self-support. We shall teach local authorities to access funds from various sources; we shall teach people to lay the foundations of small businesses, to become entrepreneurs. All these things come as an added value not only for the community but for the entire country of Romania". 
This final consideration urges us to end this paper in an optimistic note, based on the appreciation of the fact that multinationals in Romania offer many examples of best practices in the CSR field; these are examples that can and should be disseminated to all levels of economic and social life.

\section{Conclusion}

Currently, the CSR issue has become steadily rooted in the international business agenda. The research conducted thus far on the subject has focused mainly on MNCs from developed countries in North America and Europe; this largely overshadows the amplitude of the CSR phenomena in emerging markets ( $\mathrm{Li}$, Fetscherin, Alon, \& Lattemann, 2010). This article attempts to fill the gap by focusing on the CSR awareness and implementation by MNCs from Romania. The main findings of our research can be summarized as follows: (1) CSR has become increasingly important for the Romanian public and companies over the last few years due to the presence and the intense activities performed by MNCs, which successfully transferred their organizational culture and practices to their subsidiaries in emerging countries; (2) Furthermore, MNCs originating from Romania (see the case of Petrom OMV) entered into existence and undertook the role of proffering outstanding examples of suitable CSR practices that are disseminated within the overall Eastern European area; (3) The incomplete knowledge and involvement of local companies in CSR programs (despite MNCs' penetration into the Romanian market in the early 1990s) remain one of the main weaknesses of CSR in Romania, and this is revealed by the SWOT analysis. Other weaknesses revealed by our analysis were the following: insignificant investment funds and acquisitions directed at CSR domains; the use of CSR as an efficient PR instrument rather than as a long-term business philosophy; and a low coherence between the company's CSR policies and the global business strategy. (4) The main strengths were the following: a growing number of companies are involved in CSR programs; they are implementing increasingly more original and diverse projects. We are witnessing a widening interest by the public in the CSR programs initiated by the MNCs originating from Romania; and (5) From a practical perspective, it is worth noting the paradigm change from the philanthropic CSR ap- proach to the strategic CSR approach, which is obvious at the national level, and in Petrom's case, this entails a more powerful contribution of the company to the welfare of Romanian society.

A future avenue of research that we intend to explore is the possibility of developing a theoretical model to establish the thematic representation of the best CSR programs and activities, which may be followed by other companies operating in similar branches or in affiliated sectors.

\section{References}

Alchian, A., Demsetz, H. (1972). Production, Information Costs and Economic Organization. The American Economic Review, 62(5), 777-795.

Anca, C., Aston, J., Stanciu, E., \& Rusu, D. (2011). Responsabilitate Socială Corporativă în România. Analiză situaţională şi recenzie a practicilor actuale [Corporate Social Responsibility in Romania. Situational Analysis and Review of Current Practices]. Raport realizat în cadrul Proiectului POSDRU/64/3.3/S/41722 Întărirea capacităţii companiilor româneşti de dezvoltare a parteneriatelor sociale - RSC [Report within SOPHRD/64/3.3/S/41722 Project - Strengthening the Capacity of Romanian Companies to Develop Social Partnerships - CSR]. Retrieved from http://undp.ro/ libraries/projects/CSR/deliverables/Analiza\%20Situatiei\%20RSC\%20in\%20Romania\%20RO(1).pdf

Abrams, F. K. (1951). Management's responsibilities in a complex world. Harvard Business Review, 29, 29-34.

Băleanu, T. E., Chelcea, L. \& Stancu, A. (2011). The social responsibility of the top 100 Romanian companies. An analysis of corporate websites. Amfiteatru Economic, 13(29), 235-248.

Barry, N. P. (2000). Controversy: Do corporations have any responsibility beyond making a profit? Journal of Markets and Morality, 3(1), 100-107.

Bibu, N., Năstase, M., \& Gligor, D. C. (2010). The Perception over corporate social responsibility in Romania. Review of International Comparative Management, 11(5), 764-778.

Bondy, K., Moon, J. \& Matten, D. (2012). An Institution of Corporate Social Responsibility (CSR) in Multi-National Corporations (MNCs): Form and Implications. Journal of Business Ethics, 111(2), 281-299. http://dx.doi.org/10.1007/s10551-012$1208-7$ 
Botezatu, L. (2012, August 30). Petrom a investit anul trecut 4,2 milioane euro in comunitati [Petrom invested last year 4.2 million euros in communities]. Retrieved from https://www.csrmedia.ro/ petrom-a-investit-anul-trecut-42-milioane-euroin-comunitatile-in-care-activeaza/.

Bowen, H. R. (1953). Social responsibilities of the businessman. New York, NY: Harper \& Row.

Brammer, S. J., Jackson, G. \& Matten, D. (2012). Corporate social responsibility and institutional theory: New perspectives on private governance. Socio-Economic Review, 10(1), 3-28. https://doi. org $/ 10.1093 / \mathrm{ser} / \mathrm{mwr} 030$

Braun, R. (2009). Cartea Responsabilităţii Sociale Corporative. Rapoarte scurte ale companiilor româneşti [The Book of Corporate Social Responsibility. Brief Reports of Romanian Companies]. București: Braun \& Partnets S.R.L.

Carroll, A. B. \& Buchholtz, A. K. (2003). Business and Society. Ethics and Stakeholder Management (5th ed.). Mason, OH: Thomson South-Western.

Carroll, A. B. (1999). Corporate social responsibility. Evolution of a definitional construct. Business \& Society, 38(3), 268-295. http://dx.doi. org/10.1177/000765039903800303

Chamber of Commerce and Industry of Romania. (2007). CSR and Competitiveness - European SMEs' Good Practice - National Report Romania. Vienna: KME Forschung Austria.

Coelho, P. R. P., McLure, J. E., \& Spry, J.A. (2003). The social responsibility of corporate management: A classical critique. Mid-American Journal of Business, 18(1), 15-24.

Commission of the European Communities. (2001, July 18). GREEN PAPER - Promoting a European framework for Corporate Social Responsibility. Brussels, COM (2001) 366 final. Available at http://www.europarl.europa.eu/meetdocs/committees/deve/20020122/com(2001)366_en.pdf

Dahlsrud, A. (2008). How corporate social responsibility is defined. An analysis of 37 definitions. Corporate Social Responsibility and Environmental Management. 15(1), 1-13. http://dx.doi. org/10.1002/csr.132

Dumitru, V., Ionescu, I., Calu, A. \& Oancea, M. (2011). An investigation regarding the disclosure of corporate social responsibility information for listed companies from Romania. Amfiteatru Economic, 13(29), 146-162.

Dura, C. \& Isac, C. (2012). Corporate social responsibility concept within the Romanian multinational companies. Theoretical and practical aspects. Annals of the University of Craiova, Economic Sciences Series, 3, 197-208.

Dvorak, P., Guth, R., Landers, P., \& Zaun, T. (2000, December 28). Japan's embrace of Western funds leads to a forced trade détente. The Wall Street Journal. Retrieved from https://www.wsj.com/articles/SB977961954120368581

European Commission. (2011, October 25). Communication from the Commission to the European Parliament, the Council, the European Economic and Social Committee and the Committee of Regions. A Renewed EU Strategy 2011-2014 for Corporate Social Responsibility. Brussels, $\operatorname{COM}(2011) 681$ final. Available at http://eur-lex.europa.eu/legalcontent/EN/TXT/PDF/?uri=CELEX:52011DC06 $81 \&$ from $=\mathrm{EN}$

Friedman, M. (1962). Capitalism and Freedom. Chicago, IL: University of Chicago Press.

Friedman, M. (1970, September 13). The social responsibility of business is to Increase its profits. New York Times Magazine. Retrieved from http:// www.colorado.edu/studentgroups/libertarians/issues/friedman-soc-resp-business.html

Freeman, R. E. (1984). Strategic management: A stakeholder approach. Boston, MA: Pitman.

Giumali, B. (2008). Global CSR Strategies and Local Realities. The Romanian Case (CSR Paper No. 45). Fondazione Eni Enrico Matei. Retrieved from http://feemdeveloper.net/attach/CSR2008045.pdf

Henderson, D. (2005). The role of business in the world of today. Journal of Corporate Citizenship, 17, 30-32.

Iamandi, I. E. (2010). Responsabilitatea socială corporativă în companiile multinaţionale [Corporate Social Responsibility in Multinational Companies]. București: Editura Economică.

Jensen, M. C. (2001). Value maximization, stakeholder theory, and the corporate objective function. Journal of Applied Corporate Finance, 14(3), 8-21. http://dx.doi.org/10.1111/j.1745-6622.2001. tb00434.x 

Wood, D. J. (1991). Corporate Social Performance Revisited. The Academy of Management Review, 16(4), 691-718. Retrieved from http://www.jstor. org/stable/258977

Zaharia, R. M. \& Grundey, D. (2011). Corporate Social Responsibility in the Context of Financial Crisis: A Comparison between Romania and Lithuania. Amfiteatru Economic, 13(29), 195-206.

\section{Acknowledgements}

The paper represents an output of the research activity conducted by the authors during the international project: COST 281/2009 Brussels, Action IS0905 - The Emergence of Southern Multinationals and their Impact on Europe. 